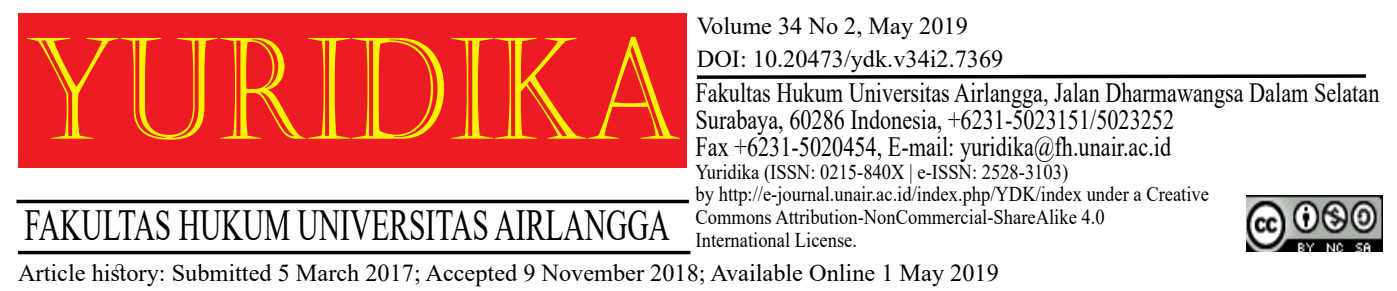

\title{
Legal Protection of Industrial Design Information and Communication Technology Based on Creative Economy to Improve Community Competitiveness
}

\author{
Abdul Atsar \\ abdul.atsar@staff.unsika.ac.id \\ Universitas Singaperbangsa Karawang
}

\begin{abstract}
Law is very influenced on the development of Technology. The current legal tool has no readiness so that it can not keep up with the rapid technological advances. The purpose of this article is to analyze the application of regulation on protection system and law enforcement of ICT design based on creative economy to improve people's competitiveness. Data analysis technique by qualitative normative descriptive method.The regulation of the legal protection system of industrial design of ICT, in Law No. 31 Year 2000, has not been regulated explicitly about the element of novelty, the application of constitutive stelsel cause obstacles. The law enforcement of ICT design is not yet effective, because of three aspects: 1) The legal substance aspect is not yet explicitly regulated about the novelty element in Industrial Design terms and the qualification and classification of the object of Right, the substantive requirement of Right of Industrial Design, the provisions of sanctions that distinguish between rights violations caused by the substance of the "same" and "similar" Industrial Design Designs registered for commercial purposes; 2) the aspect of its law enforcers, there is no appeal commission of industrial design, law enforcers have not understood the substance of the provisions of industrial design law; 2) Legal culture aspect. Indonesian society is still communal.
\end{abstract}

Keywords: Legal Protection; ICT Industry Design; Competitiveness; Creative Economy.

\section{Introduction}

The issue of protection and law enforcement against industrial design in business practices, especially in the field of information technology and communication is a separate problem. Such conditions are caused by many factors that exist in the community, including juridical factors, management procedures, period of protection, and lack of full understanding of the importance of protecting Industrial Designs. Sociologically, many designs owned by designers and business actors are not listed, so they do not get legal protection. This is due to economic 
factors, which become the financial constraints of industrial design owners to finance their design registration. ${ }^{1}$ In terms of economic considerations basically there are no obstacles because the official cost of registration industrial design is relatively affordable by the craftsmen. However, due to the lack of understanding of the importance and benefits of industrial design protection for its business, it is the cause of the craftsmen who do not want or tend to ignore the protection of the design of the works produced as long as there are no legal problems. Craftsmen will reactively care about the importance of industrial design protection when legal problems have arisen.

The development of Information and Communication Technology industry increasingly rapidly, this gives effect to the law of industrial design. The readiness and understanding of community law that has not compensate for the consequences arising from the utilization of Information and Communication Technology, whereas the field of Information and Communication Technology has a very close relationship to the development of Intellectual Property law. The term Information Technology and Communications (ICT), ie all technologies related to the collection, collection (acquisition) processing, storage, dissemination, and presentation of information. ${ }^{2}$ It includes all hardware, software, content and computer or telecom instructors.

Industrial design is a creation that is more directed towards the form of design and aesthetic value of the product form although in the legal terminology the aesthetic value in question does not have clear boundaries, but psychologically it must be admitted that the form of design greatly affects the appearance of a form. ${ }^{3}$ Industrial design in the field of Information and Communication Technology,

${ }^{1}$ Budi Agus Riswandi, 'Melindungi Desain Yang Tidak Terdaftar' (2007) 40 Majalah Handicraft Indonesia.[56].

${ }^{2}$ Kementerian Negara Riset dan Teknologi, Buku Putih Penelitian Pengembangan Dan Penerapan IPTEK Bidang Teknologi Informasi Dan Komunikasi Tahun 2005-2025 (Kementerian Negara Riset dan Teknologi 2006).[56].

${ }^{3}$ Randy Prasetyo Utomo, 'Hak Desain Industri Saklar Putar (Switch Gear) Ditinjau Dari Undang-Undang Nomor 31 Tahun 2000 Tentang Desain Industri’ (2013) 2 Calyptra: Jurnal Ilmiah Mahasiswa Universitas Surabaya <http://journal.ubaya.ac.id/index.php/jimus/article/view/781>.[2]. 
includes special design forms, configurations, patterns and ornaments. Legal awareness in developed countries, such as Korea, registration of industrial design is very extraordinary and capable of breaking down the country's economy, inversely proportional to Indonesia. ${ }^{4}$

Law of the Republic of Indonesia No. 31 of 2000, providing protection against Industrial Design. The Industrial Design Law has a fairly good concept and purpose, but factually based on empirical findings found a number of sociojuridical obstacles that concern the substance aspects of the Industrial Design Law. ${ }^{5}$ Law of the Republic of Indonesia No. 31 of 2000, provides protection against Industrial Design. However, there are still weaknesses in terms of substance, registration procedures and law enforcement. Weaknesses from the substance aspect are related to terms, object of rights, application for registration, exclusive rights, previous users, conditions for granting, implementation of industrial designs by the Government, revocation of registration of industrial design rights by the Minister, and so on. The disadvantages of the registration procedure aspects are related to the granting of rights without substantive examination and industrial design protection system. The weakness of law enforcement aspect is related to the absence of appeal commission of Industrial Design as an independent special agency having duty and authority to check the existence of rejection which is substantive to the application of industrial design right and sanction provision which must be distinguished between violation of rights caused by design substance have similarity overall and similarities registered for commercial purposes.

The Industrial Design Law must pay attention to national interests including building an industry based on the results of Indonesia's own creativity and innovation in the field of Industrial Design. The Legal Protection Model The designer through the paradigm towards adjusting/aligning the Industrial Design

\footnotetext{
${ }^{4}$ Ranti Fauza Mayana, Pelindungan Desain Industri Di Indonesia Dalam Era Perdagangan Bebas (Grasindo 2004).[48].

5 Yuliasih, 'Perlindungan Hukum Desain Industri Dalam Pelaksanaan Prinsip Keadilan Menurut Teori Dan Keadilan Jhon Rawls (Studi Kasus Putusan No. 35 PK/Pdt.Sus-HKI/2014)' (2015) 8 Notarius <https://ejournal.undip.ac.id/index.php/notarius/article/view/10263>.[152].
} 
Law in accordance with national interests, is carried out with harmony, conformity, harmony, compatibility and balance, ${ }^{6}$ with the roots of Indonesian culture so that the unique creations of the Indonesian nation can be protected. In addition, the Industrial Design Law must also accommodate international interests because Indonesia is part of the international community.

Violations of industrial design rights are still prevalent, cases of industrial design violations including Apple v. Iphone 3G case. Galaxy S Samsung Electronics Co.Ltd, case of cancellation of industrial design rights "Plastic Furniture/Furniture in 2004, case of cancellation of industrial design rights" Garuda Motorbike "in 2005, case of cancellation of industrial design rights" Saw Machine STIHL “in 2005; and industrial design rights cancellation case "Boiler Machine" between PT. Basuki against PT. Hitachi in 2010. The problem in this study regarding the application of the regulation regarding the protection and law enforcement system of industrial design in the field of Information and Communication Technology in Indonesia?.

This study uses normative juridical research methods, namely through a scientific procedure to find a truth based on the logic of science from the normative side whose object is the law itself. ${ }^{7}$ The use of this type of research, the authors look from two points of view that is first, from a juridical point, where researchers try to examine the laws and regulations applicable law; Second, from the normative aspect, the author tries to analyze the problems that exist in the rules or norms.

The approach that writer use in this research, that is by using three kinds of approach: First, approach of Legislation, that is research conducted to examine law products to be studied; ${ }^{8}$ Second, the conceptual approach, this approach is done because it is not yet or there is no legal rule for the problems that researchers face; ${ }^{9}$ Third, the case approach, carried out by reviewing cases of industrial design rights violations. This research is analytical descriptive, by describing the condition of

\footnotetext{
${ }^{6}$ Sukarmi, 'Desain Industri : Studi Model Perlindungan Hukum Berbasis Nilai' (2014) 43 Masalah-Masalah Hukum <https://ejournal.undip.ac.id/index.php/mmh/article/view/9348/7548>.[435].

${ }^{7}$ Johnny Ibrahim, Teori \& Metodologi Penelitian Hukum Normatif(Bayumedia 2011).[575].

8 Bahder Johan Nasution, Metode Penelitian Ilmu Hukum (Mandar Maju 2008).[92].

9 Peter Mahmud Marzuki, Penelitian Hukum (Kencana 2011).[137].
} 
the object under study and a number of factors that influence it, the data obtained collected, compiled, described, and then analyzed. Descriptive research aims to describe something in the place and at a certain moment. ${ }^{10}$ Sources of data used in this study, namely secondary data, consisting of:

1. Primary legal materials, is binding materials, such as jurisprudential legislation and treaties; ${ }^{11}$

2. Secondary legal materials, namely all legal materials that provide explanations of primary legal materials, such as journals, reference books, the work of scholars, research results that examine the legal issues. The main secondary legal materials are the books of law books including theses, legal dissertations, explanations of the Law and legal journals; ${ }^{12}$

3. Tertiary legal materials, namely all legal materials that provide guidance/ explanation of primary and secondary legal materials, such as articles in journals or newspapers. ${ }^{13}$

In this study the authors use data collection techniques by literature study through cataloging first, by looking at a list that provides information about the collection of libraries in which the author conducted research. Furthermore, the author studied the books and literature related to the topic of the problems that the author took in this study. In addition to literature studies, this research is also conducted through cyber media, by searching for information and news related problems in this study.

Analytical technique in this research is descriptive normative qualitative. The data obtained from the literature search is then analyzed by depicting the overall subject matter, then analyzing the data according to the quality and correctness then connected with the theory obtained from the literature study and the applicable legal provisions, to get answers to the problems in the research. Then concluded by

\footnotetext{
1998).[35].

${ }^{10}$ Soerjono Soekanto, Penelitian Hukum Normatif Suatu Tinjauan Singkat (Rajawali Press

${ }^{11}$ ibid.

${ }^{12}$ Suratman and H. Phillips Dillah, Metode Penelitian Hukum (Alfa Beta 2012).[155].

${ }^{13}$ Soerjono Soekanto (n 10).Op.Cit.[13].
} 
using deductive thinking. After data analysis, the research results will be presented descriptively, by telling and describing what it is in accordance with the problems studied. ${ }^{14}$ Then concluded by using deductive thinking.

\section{The Application of the Regulation Regarding the Protection System of Industrial} Design in the Field of Information and Communication Technology in Indonesia

Definition of industrial design according to Law No. 31 Year 2000, Article 1 number 1 is a creation of the form, configuration, or composition of lines or colors or lines and colors, or a combination thereof which is in the form of threedimensional or two-dimensional which gives the impression of aesthetics and can be realized in a three-dimensional pattern or two dimensions and can be used to produce a product, item, industrial commodity or handicraft.

Information and Communication Technology (ICT) can be categorized which includes: 1) Telecommunication technology, namely technology that covers activities related to transmitting, sending and/or receiving of any information in the form of signs, conditions, writing, images, sounds, and sound through a wire, optical, radio or other electromagnetic system. This technology is used for the operation of telecommunications in the form of the operation of telecommunications networks and telecommunications services; 2) Broadcasting Technology, which is technology that includes broadcasting activities through transmission and/or transmission facilities on land, in the sea or in space by using radio frequency spectrum through air, cable and/or other media to be received simultaneously and simultaneously by the public with broadcast receiving devices. Broadcasting technology consists of technology that supports two main broadcasting activities, namely radio broadcasting and television broadcasting; 3) Information Technology Application, which is an activity in the application of information technology in the activities of utilizing information technology by humans. The information technology in question is announcing, analyzing, and/or disseminating information.

${ }^{14}$ H.B. Sutopo, Metodologi Penelitian Hukum Kualitatif Bagian II (UNS Press 1998).[37]. 
Information technology applications especially in particular are closely related to electronic information and documents. ${ }^{15}$

Design is an activity that really requires skills in the field of graphics and computers. Not only that visual ideas are also needed to form an attractive appearance of a product, including packaging. Computers are made with the intention of helping and facilitating human work. Computers in general are composed of two components, namely hardware and software. Hardware is all physical parts of a computer, the identity that distinguishes hardware is the data in it or operates in it. Software is data that is programmed and stored digitally that is not physically visible but is contained in a computer.

The most important aspect in trade is the competitiveness of a product as one of the strategies to enter the export market. Competition is a reflection of the ability to win market share. In the world of commerce, all kinds of products created through creativity should be able to be superior to products originating from other countries, in the form of products that are in the market and other similar products. One of the products in the field of Information and Communication Technology is mobile phone as one of creative product. Adoption of cellular phone as one of creative product. Technological advances in particular mobile telephones so quickly, accompanied by internet support will spawn new types of information technology. All this is due to the creative excellence of the actors behind the creation and development of mobile phone technology. The importance of legal protection of Information and Communication Technology will support an increase in the creative economy, which is one of the government's development programs, by intensifying various information and creativity that relies on ideas, ideas and knowledge of Human Resources as the main production factors in its economic activities.

The history behind the protection of Industrial Design is a combination of copyright law and design. Industrial design is more practical and commercial use, and mass-functional product. The main objective of industrial design law is

\footnotetext{
${ }^{15}$ ibid.[260-261].
} 
to enhance and protect IPRs related to the form, configuration or ornamentation of an item that has an important contribution in the development of industry and handicrafts. ${ }^{16}$ An industrial design should be applied to an item produced through a process or an industrial tool and should be visible on finished goods made by machine, but also handmade items, which can be registered. In this case the quantity of an item is concerned, so that a single singular item can not be listed, for example such as the creation of art that can not be reproduced and architectural works. ${ }^{17}$

The industrial design protection system in Indonesia is seen from the aspect of the procedure, is a combination of copyright and patent systems. The granting of industrial design rights without examination due to the absence of objection, which is applied in accordance with Article 29 paragraph (1) and the substantive examination if there are objections or opposition, as Article 26 paragraph (5). ${ }^{18}$

Definition or definition of industrial design contained in Article 1 paragraph 1 of Law No. 31 of 2000, still has weaknesses in its implementation, so that in practice business actors and designers often submit applications for the protection of industrial designs on an object that does not fall into the category of industrial design as referred to in the Act. Definition of Industrial Design in Article 1 paragraph 1 of Law No. 31 of 2000, seems individualistic which stands out in external forms without animating and does not reflect the sense of justice or togetherness as in accordance with Indonesian culture or culture. ${ }^{19}$ The aesthetic impression element that plays an important role in industrial design turns out that in the articles which regulate the definition and granting of industrial design rights also do not include the aesthetic impression in it, so that it can be questioned the use of the aesthetic impression itself. Design in relation to the product means the overall appearance of the product that is produced from one or

\footnotetext{
16 Rahmi Jened, Hak Kekayaan Intelektual: Penyalahgunaan Hak Ekslusif (Airlangga University Perss 2010).[198-199].

17 Andrieansjah Soeparman, Hak Desain Industri Berdasarkan Penilaian Kebaruan Desain Industri (Alumni 2013).[127].

18 Ansori Sinungan, Perlindungan Desain Industri: Tantangan Dan Hambatan Dalam Praktiknya Di Indonesia (Alumni 2011).[260].

${ }^{19}$ Sukarmi (n 6).[431].
} 
more visual features of the product. An assessment of whether a creation gives an “aesthetic impression" will cause debate because Law No. 31 of 2000 concerning Industrial Design does not regulate the notion of aesthetic impressions. Aesthetic impressions are things that are abstract and can be different for everyone, thus causing legal uncertainty. ${ }^{20}$ This can be one of the factors causing violations of industrial design because of the lack of qualifications to be stated that the design has an 'aesthetic impression'.

Designers are given the Right of Industrial Design, namely exclusive rights granted by the state to the designer for his creation for a certain period of time implementing it himself, or giving his consent to other parties to exercise this right. The economic rights stipulated in the Industrial Design Law are given to the first registrants who succeed in finding new industrial designs, and this industrial design rights are exclusive. ${ }^{21}$ The period of protection for industrial design rights is 10 (ten) years from the date of receipt. The date of entry into force of the protection period as referred to is recorded in the General Register of industrial designs and announced in the Official Gazette of Industrial Designs.

The designer or the assignee, within such period may file a civil suit or criminal suit to any person who knowingly and without his consent makes, uses, sells, imports, exports and/or distributes goods granted industrial design rights. The requirement to grant industrial design rights is to have the principle of novelty. It is considered new if on the date of receipt of the industrial design is not the same as the date of disclosure with the previous date. Good disclosure made through print or electronic media, including participation in an exhibition. Previous disclosures are design disclosures prior to the acceptance date or priority date if the application

\footnotetext{
${ }^{20}$ Sindu Banyusekti, 'Tinjauan Yuridis Mengenai Penggunaan Kesan Estetis Terhadap Perlindungan Suatu Desain Industri Dalam Undang-Undang Nomor 31 Tahun 2000Tentang Desain Industri' (2013) 29 Jurnal Wawasan Hukum <http://ejournal.sthb.ac.id/index.php/jwy/article/ view/68>.[856].

${ }^{21}$ Muchtar A H Labetubun, 'Aspek Hukum Perlindungan Desain Industrikerajinan Kerang Mutiara Dalam Pemberdayaan Usaha Kecil Di Kota Ambon' (2011) 17 Jurnal Sasi < https://fhukum. unpatti.ac.id/publication/penelitian-publikasi/63-aspek-hukum-perlindungan-desain-industrikerajinan-kerang-mutiara-dalam-pemberdayaan-usaha-kecil-di-kota-ambon $>$.[51].
} 
is submitted with priority rights has been announced or used in Indonesia or outside Indonesia (Article 2 of Law No. 31 of 2000 concerning Industrial Design).

A design not deemed announced has not been deemed announced if within a period of not later than six months prior to the date of receipt, the Industrial Design has been shown in a national or international exhibition in Indonesia or abroad that is official or recognized as official or has used in Indonesia by Designers in the framework of experiments with the aim of education, research or development. What is meant by official exhibition is an exhibition organized by the government. While exhibitions that are recognized as official are exhibitions held by the community, but are recognized or obtain governmental approval. ${ }^{22}$

The Industrial Design Act explicitly requires the existence of an element of novelty, but in practice the understanding of the element of novelty still creates multiple interpretations so that many problems are found in the field. In Article 2 of the Industrial Design Act, provides that industrial design rights are granted for new industrial designs; industrial design is considered new if on the date of receipt and design of the industry is not the same as the existing disclosure. The "novelty" element becomes one of the considerations in granting industrial design rights. Weakness of Law No. 31 of 2000 on Industrial Design, does not apply the original approach, only emphasizes the novelty. Law No. 31 of 2000 on Industrial Design, does not expressly apply the novelty principles used, resulting in legal uncertainty on the application of the principle of novelty in the protection of industrial design in Indonesia. Not a single Article explains the novelty principle of a registered industrial design so that in practice the interpretation of the provisions of that Article shall be submitted to the judge in court if a dispute arises.

In industrial design law, the criterion of novelty criteria is the same as the Criteria of novelty in the Patent law as referred to in Articles 5 and 6 of Act no. 13 Year 2016 About Patents. The difference is that the novelty in Industrial Design refers to an aesthetic form or configuration. While on Patent (Patent product in this

${ }^{22}$ Ermansyah Djaja, Hukum Hak Kekayaan Intelektual (Sinar Grafika 2009).[380]. 
case Simple Patent) more new product. In practice in Indonesia the assessment of industrial design novelty, whether carried out by industrial design inspectors on the registration process conducted by the Intellectual Property Rights office or in case of cancellation of industrial design rights in the Commercial Court, there is often a problem in providing an assessment of this novelty, design that has similarity.

The application of the determination of the criteria for the word "not the same" in Law No. 31 of 2000, Article 2 paragraph 2 has caused problems, especially in several industrial design cases at the Commercial Court and has obtained the Commercial Court's decision, among others: the case of cancellation of industrial design rights "Plastic Furniture/Furniture in 2004, case of cancellation of design rights the "Garuda Motorbike" industry in 2005, the case of the cancellation of industrial design rights "Saw Machine STIHL" in 2005; and industrial design rights cancellation case "Boiler Machine" between PT. Basuki against PT. Hitachi in 2010.

In case of cancellation of industrial design rights "Garuda Motorcycles" there has been difficulty in assessing the comparison of two industrial designs namely Honda motorcycle industry design with Garuda motor which became the object of dispute. Overall between the two industrial designs have the impression and look the same, but there are several elements or components and different parts. At the first level of the Commercial Court, the judge ruled that the design of Garuda motorcycles had a "novelty", but on the appeal level of the Supreme Court, the Supreme Court argued and stated that the design of the Garuda motorcycle industry had no element of novelty because the design had been registered by Honda although there is a slight difference. Another example, namely the cancellation of Industrial design rights in the form of "Saw Machine STIHL". In addition, the case regarding industrial design, namely the case of the Ballpoint Pen industrial design. The issue of novelty also becomes an issue where Defendant I submits an Industrial Design Registration entitled "PENA BOLPOIN" with registration number ID0023602D dated July 28, 2011 is in bad faith because the registered has been revealed previously and registered on behalf of Plaintiff "KENKO EASY GEL “, so that the registration of Defendant I is the result of a clone or a copy of the industrial design of another person. 
In the case of Iphone 3G Industrial Design Apple Inc. V. Samsung Galaxy S Elektronics Co.Ltd in USA. In that case, it shows that in the application of the novelty principle adheres to the provisions that are in line with article 25 paragraph (1) TRIPs, namely using the significantly diferent method. The design of the Samsung Galaxy S i9000 is considered to violate some of the industrial design rights that Apple has over the iPhone 3GS because both have designs that resemble one another and do not appear to be significant differences between the two cellphone designs. The new design should not resemble the existing design in advance even though there are differences in the design that the previous design has, but if the difference lies only in minimal differences, it is related to just a few elements, both the color and the curvature of the outer cross section, as long as it looks in plain view, the design cannot be considered a new design. This provision has not been fully adopted by Law No. 31 of 2000 on Industrial Design. Examples of cases as mentioned above, indicate the existence of a very basic problem regarding aspects of legal certainty regarding the assessment of "novelty" of an industrial design.

There is a legal uncertainty in the decision of the Commercial Court and the Supreme Court which continues until the level of Review (PK). At the first level court, the Jakarta Commercial Court decided based on the interpretation that the word "not the same" meant "not substantially the same". At the cassation level it was decided based on the interpretation that the word "not the same" was interpreted as "not identical" (not exactly the same), and finally at the Judicial Review level, the judge's decision to use the basis of judgment as in the Commercial Court's decision, which was decided based on the interpretation that the word "no the same" is defined as" not substantially equal". Such conditions have led to legal uncertainty regarding the "ownership limit" of industrial design rights that are essentially determined by the "novelty" of industrial.

Legal protection can be given preventively by the government with the aim of preventing disputes, while refractive legal protection is the protection of industrial design rights from actions taken by parties who use industrial design rights of other parties against the law or without rights. Industrial design including 
industrial property rights, which adhere to the fist to file protection system, that is, protection is given to the first registrant. Exclusive protection related to moral rights and economic rights. Application of Article 10 jo. Article 12 of the Industrial Design Law, which regulates the subject of registration (first to file), namely the failure to register rights to industrial design works by the designer will result in the designer not getting legal protection and not legally entitled to his design work. Legal protection is given to parties who register for the work and have evidence in the form of industrial design registration certificates.

The implementation of a constrictive standard for industrial design law design creation in order to guarantee legal certainty, but for the design of the Information Technology and Communication industry that is fast-changing, the implementation of the technology creates constraints namely protection becomes ineffective because it does not fit the background of the Law Act on Industrial Design and the achievement of legal objectives in a comprehensive manner, namely legal certainty, justice and expediency. In connection with the field of Information and Communication Technology, there are 3 (three) alternative legal protections, namely Law No. 31 of 2000, Law No. 28 of 2014 and Law No. 13 Year 2016 About Patents. For computer programs in Indonesia protected by copyright (Law No. 28 of 2014 concerning Copyright), Article 40 paragraph (1). One of the creations that can be protected is a computer program. As for the hompage there are two options, namely Law No. 31 of 2000 or Law No. 28 of 2014.

\section{Law Enforcement System of Industrial Design in the Field of Information and Communication Technology in Indonesia}

Internet development activities so fast that the protection of the homepage should be protected by the Copyright Act. It is no longer relevant to be governed by industrial design law, unless the government revises Law No. 31 of 2000 concerning Industrial Design and changing the constitutive system and turning it into a declarative system especially for the protection of the design of the Information and Communication Technology industry. A software can still be 
protected by a Patent mechanism if the software related to the computer program can solve technical problems and are related to technology and there is already a Patent certificate protection from the country of origin. Law No. 13 of 2016, Article 4 states: the invention does not cover, among others: rules and methods that contain only computer programs. Explanation of Article 4 letter d, what is meant by "rules and methods that only contain computer programs" is a computer program that only contains programs without having the character, technical effects, and problem solving, but if the computer program has characters (instructions) that have technical effects and functions to produce problem solving both tangible and intangible are inventions that can be granted a patent.

Mastery of science and technology of Indonesian society today, need to be harmonized with the world's demand for creative work. The digital age enables the relationship of creative people across cultures and nations, this condition will create a diversity of creativity, so that there will be a clash of cultures and laws. Community creativity in the field of Information and Communication Technology industry needs to get the protection of industrial design and creation accurately and comprehensively by making rules or qualifications about copyright, patent, design and even brand in Information and Communication Technology so that there is no overlapping of rules so that will lead to ambiguity or legal uncertainty. Considering the field of Information and Communication Technology is so rapidly developing, it should be for design in this field should apply the declarative principle to protect the design of the industry, so that will improve the competitiveness of the communitybased creative economy.

There are four factors that need to be considered to develop the creative economy in general namely human capital, infrastructure, financial institutions and government bureaucracy. For human capital, the work that can be done to advance the cratic economy is through education and training. Infrastructure must be able to accommodate the progress of time, so that innovation resulting from the creative process can be more optimal. Financial institutions will play a role not only in terms of capital, but also for investment and even in terms of marketing. The estuary of 
these four important factors is the government bureaucracy. Without the full support of the government in terms of regulation, the protection of intellectual property rights, the ease of licensing will greatly help the growth of the creative economy. ${ }^{23}$

Designers or industrial design holders can make legal remedies if their rights are violated. Such legal remedies can be carried out through two lines, namely civil and criminal channels. Civil service efforts can be done to sue violators of industrial design rights to the Commercial Court and can also use the Alternative Dispute Settlement Institution, such as negotiation, mediation and conciliation as stipulated in Article 47 of Law No. 31 of 2000. Arbitration can be conducted domestically or abroad. If there is a criminal act of industrial design it can be resolved through a criminal process by reporting the criminal action to the authorities.

Holders of industrial design rights or license recipients can sue anyone who intentionally and without rights commits making, using, selling, importing, exporting, and/or distributing goods that are granted industrial design rights with compensation claims and/or termination of such actions. The lawsuit was submitted to the Commercial Court (Article 46 paragraph 1 and 2 of Law No. 2000). If the dispute contains criminal elements or violates Article 54 paragraphs 1 and 2, which states that:

“(1) Any person who intentionally and without right to act Article 9 shall be sentenced to a maximum imprisonment of four years and/or a fine of a maximum of Rp. 300,000,000.00. (2) Anyone who deliberately violates the provisions of Article 8, Article 23, or Article 32 shall be sentenced to imprisonment for a maximum of one year and/or a fine of a maximum of Rp. $45,000,000.00 "$.

If a violation occurs in the form of making, using, selling, importing, exporting, and/ or circulating goods that are given Industrial Design Rights, violates the designer's moral rights, violates the obligation to maintain confidentiality of the application until the application is announced, it can be reported to the investigator for then it is processed in accordance with the provisions of the Criminal Procedure Code

\footnotetext{
${ }^{23}$ Yassinta Ben Katarti LD, 'Saatnya Ekonomi Kreatif Pegang Kemudi Perekonomian' (Humas Lombok, 2017) <https://humas.lombokbaratkab.go.id/saatnya-ekonomi-kreatif-pegangkemudi-perekonomian/> accessed 10 January 2018.
} 
(KUHAP). Industrial design crime is a type of complaint offense. This offense can only be convicted if there have been reports from parties who feel aggrieved in this case the industrial design rights holders who have been harmed by the use of industrial design rights without rights and against the law.

Legal remedies that can be carried out by industrial design holders in addition to the above are the Provisional Determination that can be carried out by the parties to the dispute. Based on sufficient evidence, the party whose rights have been disadvantaged may request the judge of the Commercial Court to issue a temporary decree concerning the prevention of product entry related to the violation of the Right to Industrial Design and the retention of evidence relating to violations of the Right to Industrial Design. The stipulation is intended to prevent the occurrence of greater losses of parties whose rights have been violated and to prevent further violations and the entry of goods suspected of violating the Right to Industrial Design (Article 49 s.d 52 of Law No. 31 of 2000 concerning Industrial Design).

Non-Litigation Settlement is done outside the court, this settlement is chosen if the parties want to get a solution and settlement without going through litigation (court). This Non-Litigation Settlement can be chosen by industrial design rights holders and parties who violate their rights by settling out of court through negotiation, mediation and conciliation and arbitration. Arbitration is a judicial institution held by and based on the will and goodwill of the disputing parties so that their dispute can be resolved by the arbitrator they appoint and the decision taken by the arbitrator is a final and binding decision on both parties. ${ }^{24}$

According Soekanto, said that the factors that influence law enforcement, namely the legal factors themselves, law enforcers, facilities or facilities that support law enforcement, society and culture. This factor is a measure of effectiveness. ${ }^{25}$ If all four of these factors have been synergistic, industrial design law can stand up, because the enforcement of industrial design law is very dependent on the legal

\footnotetext{
${ }^{24}$ Gunawan Widjaja and Ahmad Yani, Hukum Arbitrase (PT Raja Grafindo Persada 2000).[16].

${ }^{25}$ Soerjono Soekanto, Pengantar Penelitian Hukum (UI Press 1986).[3].
} 
factor itself/legal substance governing industrial design, law enforcement officials have comprehensively understood industrial design law, supporting facilities law enforcement such as courts, the public has understood substantially about industrial design law and has a legal culture that respects and realizes the importance of legal protection against industrial design.

\section{Conclusion}

The Industrial Design Act has not yet set firmly on the design of the Information and Communication Technology (ICT) industry, so there is no legal certainty, the implementation of constitutive stelsel makes legal protection ineffective, thus implicating the non-achievement of legal objectives. Industrial design law enforcement has not been effective, because of three aspects: 1) Aspects of legal substance, namely not yet explicitly regulated about the qualifications of the element of novelty in terms of Industrial Design, object classification, substantive requirements for granting Industrial Design Rights, as well as the provision of sanctions that distinguish between rights violations caused by industrial design in substance "the same as a whole", similar to registered industrial designs for commercial purposes; 2) Aspects of the Law Enforcement, namely the lack of understanding of law enforcers regarding the substance of the legal provisions of Industrial Design, the lack of facilities and infrastructure that support the implementation of the Industrial Design Law and the absence of an Industrial Design appeal commission as an independent special body that has the duty and authority to examine the existence of substantive rejection of the application for the Right to Industrial Design; 3) Aspects of legal culture. Indonesian society adheres to a culture that is different from western countries that are individual in nature, which is the philosophical basis of the protection of industrial design where western society is more individualistic while Indonesian society is communal, so it tends to complicate the law enforcement of industrial design rights in Indonesia. 


\section{Bibliography}

Andrieansjah Soeparman, Hak Desain Industri Berdasarkan Penilaian Kebaruan Desain Industri (Alumni 2013).

Ansori Sinungan, Perlindungan Desain Industri: Tantangan Dan Hambatan Dalam Praktiknya Di Indonesia (Alumni 2011).

Bahder Johan Nasution, Metode Penelitian Ilmu Hukum (Mandar Maju 2008).

Budi Agus Riswandi, 'Melindungi Desain Yang Tidak Terdaftar' (2007) 40 Majalah Handicraft Indonesia.

Ermansyah Djaja, Hukum Hak Kekayaan Intelektual (Sinar Grafika 2009).

Gunawan Widjaja and Ahmad Yani, Hukum Arbitrase (PT Raja Grafindo Persada 2000).

H.B. Sutopo, Metodologi Penelitian Hukum Kualitatif Bagian II (UNS Press 1998).

Johnny Ibrahim, Teori \& Metodologi Penelitian Hukum Normatif (Bayumedia 2011).

Kementerian Negara Riset dan Teknologi, Buku Putih Penelitian Pengembangan Dan Penerapan IPTEK Bidang Teknologi Informasi Dan Komunikasi Tahun 2005-2025 (Kementerian Negara Riset dan Teknologi 2006).

Law Number 31 of 2000 concerning Industrial Design (State Gazette of the Republic of Indonesia of 2000 Number 243, Supplement to the State Gazette of the Republic of Indonesia Number 4045).

Peter Mahmud Marzuki, Penelitian Hukum (Kencana 2011).

Rahmi Jened, Hak Kekayaan Intelektual: Penyalahgunaan Hak Ekslusif(Airlangga University Perss 2010).

Randy Prasetyo Utomo, 'Hak Desain Industri Saklar Putar (Switch Gear) Ditinjau Dari Undang-Undang Nomor 31 Tahun 2000 Tentang Desain Industri' (2013) 2 Calyptra: Jurnal Ilmiah Mahasiswa Universitas Surabaya <http://journal. ubaya.ac.id/index.php/jimus/article/view/781>.

Ranti Fauza Mayana, Pelindungan Desain Industri Di Indonesia Dalam Era Perdagangan Bebas (Grasindo 2004).

Sindu Banyusekti, 'Tinjauan Yuridis Mengenai Penggunaan Kesan Estetis Terhadap 
Perlindungan Suatu Desain Industri Dalam Undang-Undang Nomor 31 Tahun 2000Tentang Desain Industri' (2013) 29 Jurnal Wawasan Hukum <http:// ejournal.sthb.ac.id/index.php/jwy/article/view/68>.

Soerjono Soekanto, Pengantar Penelitian Hukum (UI Press 1986).

—_, Penelitian Hukum Normatif Suatu Tinjauan Singkat (Rajawali Press 1998).

Sukarmi, 'Desain Industri : Studi Model Perlindungan Hukum Berbasis Nilai' (2014) 43 Masalah-Masalah Hukum < https://ejournal.undip.ac.id/index.php/ $\mathrm{mmh} /$ article/view/9348/7548>.

Suratman and H. Phillips Dillah, Metode Penelitian Hukum (Alfa Beta 2012).

Yuliasih, 'Perlindungan Hukum Desain Industri Dalam Pelaksanaan Prinsip Keadilan Menurut Teori Dan Keadilan Jhon Rawls (Studi Kasus Putusan No. 35 PK/Pdt.Sus-HKI/2014)' (2015) 8 Notarius < https://ejournal.undip.ac.id/ index.php/notarius/article/view/10263>.

Yassinta Ben Katarti LD, 'Saatnya Ekonomi Kreatif Pegang Kemudi Perekonomian' (Humas Lombok, 2017) <https://humas.lombokbaratkab.go.id/saatnyaekonomi-kreatif-pegang-kemudi-perekonomian/> accessed 10 January 2018.

HOW TO CITE: Abdul Atsar, 'Legal Protection of Industrial Design Information and Communication Technology Based on Creative Economy to Improve Community Competitiveness' (2019) 34 Yuridika. 
--This page is intentionally left blank-- 